\title{
Gender Space in The House of Mirth*
}

\author{
Tingting Xie \\ School of Foreign Languages \\ Hubei University of Chinese Medicine \\ Wuhan, China
}

\begin{abstract}
Edith Wharton is one of the most influential novelists at the turn of the twentieth century in America. In 1905, with the publication of The House of Mirth, it aroused the attention of critics and caused much controversy. As a sensitive female writer, Wharton observed that the differences of space in the transitional period. This paper intends to explore the male and female space in Wharton's novel by doing a detailed analysis. It can be found that Wharton reveals the differences and inequalities of male and female space, and demonstrates the social oppression of female space.
\end{abstract}

Keywords-Wharton; The House of Mirth; space

\section{INTRODUCTION}

Edith Wharton (1862-1937) is one of the most influential novelists in American literary history. Published in 1905, The House of Mirth won immediate success, arousing the attention of readers and critics. It is a novel of manners that presents a picture of upper-class New York society at the beginning of the twentieth century. At that time, the society underwent great changes. Wharton sensed the impact of the social changes and represented it veritably. Wharton has been intensively studied in literary field. However, in her book The House of Mirth, a comprehensive understanding of gender space remains unexplored till the present. In this paper, the writer intends to employ spatial theory in the textual analysis. Spatial theories advocated by Lefebvre have recently been accepted as a popular approach in other critical practice. Hopefully, this paper will shed new light on the reading of classical works.

\section{THE CONCEPT OF SPACE}

In 1974, the French socialist, Henri Lefebvre published his most influential work, The Production of Space. The theory of modern space has been brought about in this book. The early theories of space tend to conceptualize space as passive and inert. In contrast to the assumption, Lefebvre sees space as active, fluid and vital, stating that it is "the outcome of a process with many aspects and contributing currents" (Lefebvre, 1991: 34). According to him, space is not "a system of organization, a geometry, a kind of absolute grid, within which objects are located and events occurs". Rather, as he notes, "the space is result and cause, product and producer” (Lefebvre, 1991: 142). In other words, social

*2015 Chinese University Research Projects of Foreign Language Instruction: Interpretation of Female Space in Edith Wharton's Works from Postmodern Space Theory space is produced by society, and then produces society in reverse. As a product, social space is shaped through a series of social processes and human activities. In turn, as a force, it will influence, direct and delimit the possibilities of human activities.

In the traditional gender division of labor, men were assigned to the public space meaning power and reputation, while women had to stay in their narrow space in the families indicating dependence and submission. Therefore, some traditional geographers would regard private space relating to family as feminine, while public space, where people perform social activities as masculine (Huang Chunxiao, 2008). This dichotomy of space is often criticized for its discrimination against woman's economical and political rights. In a word, people show an increasing interest to employ spatial theories to discuss the gender issues in literary works.

\section{Female SPACE IN THE House OF MIRTH}

Since the novel sets in New York at the turn of the twentieth century, Wharton was sensitive enough to notice the changes in the society. She attaches great importance to the conflicts existing in space and described them as she notices.

There used to be a labor division between work and home: men went out to make a living, while women's domain was the house. A strong belief was held that the world of work, the public space, was a dangerous world full of temptations, violence and trouble. Being a weak creature, a woman who ventured out into such a world could get hurt easily, therefore, a woman's place should be in the private space, that is to say, in the home. Consequently, women were expected to be put in the center of the domestic space, fulfilling their job of a nurturing mother and a faithful wife whole-heartedly.

\section{A. Upper Class Women}

The view that "the world of work was defined as male, the world of the home was defined as female" (ibid) was accepted and embedded in the life of the old aristocratic families. Mrs. Peniston is an icon of the rigid Victorian life. As a member of the old New Yorkers, she always lives well, dresses expensively and does little. The description of her lifestyle exemplifies exactly the meaning of "domesticity". Confining herself in the large mansion, most of her energy is given to the housekeeping. Every first two weeks of October 
represent "the domestic equivalent of a religious retreat" (p.79). She would go through all the linen and blankets. The dust on the topmost shelf of every closet, the darkest place in the cellar and coal-bin should be cleaned. And the last stage of the house-cleaning is to wash the entire house with white soap. Disliking social activities, she has a high sense of family obligation to invite newly-married relatives over for dinner. She spends days considering "every detail of the feast, from the seating of the guests to the pattern of the tablecloth" (p.99). To sum up, she obeys the rule of staying home to fulfill her task.

Faithfully conforming to the inherited obligations, she has always been a looker-on at life, never wanting to be a focus of any activities. Lily tries in vain to draw her aunt into the whirl of her own activities. " $[\mathrm{H}]$ er mind resembled one of those little mirrors which her Dutch ancestors were accustomed to affix to their upper windows, so that from the depths of an impenetrable domesticity they might see what was happening in the street" (p.29). Just as the word "domesticity" suggests here, she seldom goes into the dangerous and noisy outside world, her mansion is her castle protecting her from the bustle and hustle of the society. Ironically, reluctant to go out, she still wants to keep informed of all the news. Standing behind her upper-window, Mrs. Peniston keeps an accurate record of social ups and downs, and knows more about the distinguishing feature of every season than anyone else.

Moral purity is another distinctive feature of Mrs. Peniston. Although she boasts about her familiarity with the secrets of society, she is as innocent as a school-girl who regards wickedness as part of history. So when the scandalmonger Grace Stephney tells her about Lily's presence with Gus Trenor in the park in the afternoon, she is horrified genuinely. "She was as much aghast as if she had been accused of leaving her carpets down all summer, or of violating any of the other cardinal laws of housekeeping" (p.29). Wharton's ironic tone is explicitly sensed. And in her comparison of Mrs. Peniston's horror to violation of housekeeping laws, readers also learn the pathetic space in which the old Victorian women stay. There is nothing in her life except domestic chores.

Different from the old aristocratic women, the space of new bourgeois women had expanded beyond the concern of family and home. Generally speaking, domesticity became less confined for them at the beginning of the twentieth century. The domestic duty of a leisure-class woman was no longer to create a heaven in which her husband could retreat. They could venture out to take part in some activities in the modern cities, like paying bills, visiting stores and having dinner at the new restaurants and so on. In addition, they could even break some traditional rules, like smoking, divorcing, gambling and even having affairs. However, if we look into the text, we can find that their duties began to include consumption of material goods that would convey her husband' s success in the world. In fact, ensconced in the lavish houses, the leisure-class woman played the role as the consumer and protector of her husband's resources, still detached from the feminine urban space.
Wharton's city is a city composed of mansions and the pastoral gardens. On an evening stroll down Fifth Avenue, Lawrence Selden and Ned Van Alstyne sums up the mansions they pass. Trenor's house is "exuberant, but based on the best precedent". With the "air of improvisation", the mansion of Wellington Brys is like a "copy of the Trianon", which is built as hastily as his fortune. Simon Rosedale purchases a house, the façade of which "is a complete architectural meal" (p.130-131). Percy Gryce has "an appalling house, all brown stone without and black walnut within" (p.16). Then, we travel through these different kinds of interiors: the long corridors with rare paintings, the sittingrooms decorated with luxurious furniture, the conservatories of tropical plants and fountains. Men provide the finances and the houses, controlling what happens outside and the access to it. While women of leisure class control what happens inside the houses, displaying their men's resources in proper ways.

Judy Trenor is a typical hostess in the rich upper-class family. "Her rosy blondness had survived some forty years of futile activity without showing much trace of ill-usage". In the eyes of other people, she seems to "exist only as a hostess, not so much from any exaggerated instinct of hospitality as because she could not sustain life except in a crowd" (p.32). What makes her unhappy is that some woman may give bigger dinners or have more amusing house-parties than her. Her life will become meaningless if there are no dinners or parties. In other words, she is a comfortable lost soul.

In spite of the expansion of urban space for women, Wharton's leisure class woman still stays in the narrow interiors, intending to become a decoration most of the time.

\section{B. Working Class Women}

While focusing on women in her familiar set, Wharton never forgets to describe the young women laborers. In the opening scene, Selden recognizes Lily easily from the crowd. When they pass by the "sallow-faced girls in preposterous hats, and flat-chested women struggling with paper bundles and palm-leaf fans" (p.2), Selden starts wondering whether she belongs to the same race. Serving as background to set off Lily's charm, these dingy and crude women, including Gerty Farish and Nettie Struther, represent a different group, lower-class.

Historically, more and more young, single women went into the working market during this period. Many factories replaced male workers with machines designed for lowerpaid women to operate. Hence, working women in the literary texts at that time were described as "masculine, disloyal, promiscuous, lazy" (Connel, 1997: 569).

Historically, working class women often appeared as negative images. Gerty Farish, her name is mentioned in the discussion of women's possibility of living in a flat. Lily's answer implying that Gerty is not a marriageable girl shows the widespread attitude towards young working girls. Physically, Gerty is not beautiful. Her gray eyes and her lips without haunting curves obviously are not attractive. Although she treats people with frank smile, her sincerity is 
often considered as signs of dullness instead of signs of virtue. Most people fail to appreciate her inner beauty.

Looked down upon by most people, working-class girls are regarded as sexually accessible and have association with prostitution. "[A] woman's first step outside to the traditional home was also her first step down the road to delinquency and degeneration" (Connell, 1997: 571). Nettie Struther, a beautiful young girl who receives help in the Working Girls' Club from Lily, is once faced with what the traditionalists called moral decay. She meets a gentleman when working as a typist in a company. After their engagement, the stylish gentleman abandoned her. "Work-girls aren't looked after the way [Lily is], and they don't always know how to look after themselves" (p.256). Her story is certainly people's assumption of the danger working girls would face. Without the protection of family, they are likely to risk becoming fallen women.

Either unattractive physically or degraded morally, public criticism on working girls were always unfavorable. As new women who ventured to enter the outside world, these working women were more marginalized.

\section{Male Space in The House of Mirth}

Besides differences among women themselves, there are different standards of men and women of leisure-class in terms of conceived space.

As we said before, the providers of these mansions are men. Generally speaking, they are in charge of the outside world. In which way can they possess their power? The answer is money.

In his Theory of the Leisure Class: An Economic Study of Institutions, Thorstein Veblen defines the most distinctive characteristic of leisure is "a conspicuous exemption from all useful employment". Gentlemen in the nineteenth century were not supposed to be involved in productive labor. They might occupy their time nonproductively to prove that he has no need to work. However, the flourish of economy found its way into the lifestyle of leisure-class. The change of gentlemen's involvement in jobs is transparent evidence.

For example, Selden, a male counterpart of Lily, gets no money from his family. But he has got his own job. To him, "the work itself is not so bad, [he is] rather fond of the law" (p.8). The income at least can afford him a comfortable life.

Percy Gryce, an old aristocratic, has inherited a huge fortune "which the late Mr. Gryce had made out of a patent device for excluding fresh air from hotels" (p.17). After the family's settlement in New York, Percy spends all his weekdays working in the office "where a batch of pale men on small salaries had frown grey in the management of the Gryce estate, and where he was initiated with becoming reverence into every detail of the art of accumulation" (p.17). Unnecessary to work hard to support his family, young Gryce's job serves as a fashion rather than real devotion.

A similar case happens to Gus Trenor. His parents leave large sum of money to him so that he could maintain the decent life. But, he is more actively involved in money- making than Percy. He invests his money in the stock market and makes big profits in return. To him, working means more than a fashion. Financial investment would mean an accumulation of more fortune and a necessary way to maintain their luxurious life.

Rosedale, a shrew financier, is the emblem of the power of Wall Street. By providing some useful information on stocks to people like Gus Trenor, he successfully enters the upper-class society, exerting the power endowed by Wall Street.

Whether a fashion, or a way to make a living, or means of getting more fortune, working is a common phenomenon among men. However, the field of money-making is a domain of men, remaining a forbidden area for women.

"A man may, but a girl must [marry]" (p.8). It is a truth universally acknowledged, which is one of those double standards. Take Lily's cousin Jack for example. He seeks to rise above poverty like Lily does. When Lily is planning to tempt Percy Gryce, he is pursuing Miss Van Osburgh. The rich miss "with flat surfaces and no high lights" is remarked "as reliable as roast mutton". Jack's real taste is "in the less solid and more highly-seasoned diet" (p.37). Compared with her unappealing appearance, her large sum of money attracts the young man more. Easily, he marries the wealthy girl. Yet his female counterpart, Lily, has to try her best to get a profitable match. As Lily reflects: all a man "has to do to get everything he wants is to keep quiet and let that girl marry him; while I have to calculate and contrive, and retreat and advance, as if I were going through an intricate dance, when one misstep would throw me helplessly out of time" (p.38). In the same situation, a bachelor is always welcome, while an unmarried girl is a social obstacle. What is also different is that when a man chases a girl, he had no need to cover his intention. But for a girl, she has to be cautious lest she get a bad reputation of being on the hunt for a rich husband.

The double standards operate in other aspects. As Wharton recalls her life experience, the society denied women any real education. Boys were usually educated for the purpose of getting a proper place in the world, but girls were only trained in arts and graces in order to get a satiable marriage. Lily, a product of this system, is trained to be a housekeeper and social manager. "Isn't marriage your vacation? Isn't it what you're all brought up for" (p.38). Of course, the answer to Selden's rhetorical questions would be yes.

Hypercritical moral standard also reflect the differences. Selden has love affairs with Bertha, which is a long history that "the friends [...] had smiled and shrugged, viewing it merely as one among the countless 'good situations' of the mundane comedy" (p.38). Selden never feels ashamed of his affair, and other people take it as a joke. It is so natural for a man to do so that it seems ridiculous to make a fuss about it. Nevertheless, when it comes to Lily's suspicious liaison with George Dorset, things become completely different. Despite her innocence, people censure her and cast her out of their set. "[T]he truth about any girl is that once she's talked about she's done for" (p.183). Morality of the upper class is imposed unfairly. Indeed, these double standards indicate the 
inequality of women's and men's space, either physically or spiritually.

\section{CONCLUSION}

An expert in the decoration of houses as well as a writer, Wharton shows special concern about spaces, which is also reflected in the heroine's traveling from space to space in The House of Mirth. Wharton observes the differences between men's and women's space and describes them veritably in her story. Therefore, it is significant for us to study the story from the angle of space.

\section{REFERENCES}

[1] Connell, Eileen. Edith Wharton Joins the Working Classes: The House of Mirth and the New York City Working Girls' Clubs [J]. Women's Studies, 1997, 26:557-604.

[2] Lefebvre, Henri. The Production of Space [M]. Trans. Donald Nicholson Smith. Massachusetts: Blackwell, 1991.

[3] Huang Chunxiao Chengshi Nuxing Kongjian Yanjiu [M]. Nanjing: Southeast University, 2008

[4] Wharton, Edith. The House of Mirth [M]. New York: Dover Publications, Inc., 2002.

[5] Wu Lanxiang Gender, Race and Space: A Cultural Study of Edith Wharton's Travel Writing [M]. Nanjing: Southeast University, 2009. 